\title{
The concept of teaching the history course for students of noncore specialties
}

\author{
Roman N. Evdokimov ${ }^{1,2,3,4^{*}}$, Marina A. Kindzerskaya ${ }^{3}$, and Tatiana I. Savinchenko ${ }^{3}$ \\ ${ }^{1}$ Moscow State University of Psychology and Education, Institute of Foreign Languages, Modern \\ Communications and Management, Department of Philosophy and Humanities, Moscow, Russia \\ ${ }^{2}$ Financial University under the Government of the Russian Federation, Department of Humanities, \\ Moscow, Russia \\ ${ }^{3}$ Russian Economic University named after G. V. Plekhanov, Humanitarian Training Center, \\ Department of History and Philosophy, Moscow, Russia \\ ${ }^{4}$ Moscow State Regional University, Historical and Philological Institute, Faculty of History, Political \\ Science and Law, Department of History, Culture and Social Development of the Moscow Region, \\ Moscow, Russia
}

\begin{abstract}
This work is aimed at disclosure of features of history teaching in conformity with modernization processes in Russian higher education. The purpose of this concept is quality improvement of historical education and development of cognitive and socially important knowledge, skills and habits of students of noncore specialties (nonhistory students), economy profile first of all. The concept is based on competence and activity approaches to education. The relevance of development of this concept is dictated by high requirements of modern society to quality of history education, increased public interest to facts of Russian and foreign history, development of historical studies, accumulation of new historical knowledge. In the course of this work, the recommendations have been given regarding development of content and education plan of History discipline, which are universal and after certain adaptation can be used by teachers of other humanitarian and social disciplines. A fresh point of view is proposed on historical education as a tool of formation of system thinking of students, creation of consistent concepts of world history process, including the role of Russia and its development as a part of human civilization.
\end{abstract}

Keywords: history, learning process, higher education.

\section{Introduction}

The history knowledge taught to the students of noncore specialties (nonhistory students) in Russian universities is based on the discipline appropriately titled History. It refers to the basic part of education plan in the structure of academic program of higher education. According to the working programs of Plekhanov Russian University of Economics and Financial University, History discipline promotes formation of skills to analyze the most complex problems of world and Russian economic, political, and social spiritual

*Corresponding author: romey79@mail.ru 
development. Its objectives are: 1) understanding of main regularities and features of historical process, main stages and content of Russian history, and 2) mastering theoretical foundations and methods of its learning [1-3].

\section{Methods}

The main tasks of the discipline were comprised of formation of common cultural competences and fostering of a citizen capable to work in a team, while tolerantly accepting social, ethnical, and other distinctions. In addition, mastering of this course should result in formation of competences allowing to apply in practice the methods of humanitarian, environmental, social, and economic disciplines in various types of professional and social activities [1,3].

\section{Results}

The History course is believed not only to give firm subject knowledge to students but also to form value targets, skills based on historical collisions, objective and subjective factors of society development to infer cause and effect relationships, as well as skills to argue their own position, to reproduce and to translate information flows, which finally will facilitate future specialists' penetration into their chosen professional field [2, 4].

At the same time, it is not a secret that the scientific historical picture of the world taught in noncore departments and universities of Russia is unfortunately separated from practical reality and is not functional. In the course of teaching history, this is expressed in the preservation of approaches to isolated consideration of the Russian past out of the context of general trends of the world civilization development. Frequently or even usually there are attempts to teach truncated courses of history, which disclose exclusively the development of Russian history in Modern and Contemporary times, that is, from the end of the15th century to the end of the20th century. Herewith, the interrelation between Russian and foreign history is poorly traced, historical development is studied only in the political frames of events, without attention to social, cultural, and other aspects, and the most important is that the base of historical knowledge, the theory as such, is poorly explained [5].

Moreover, there is certain kind of widely spread forgery related with inconsistency of the title of History course to its content. The fact is that in some universities for nonhistory students of various specialties, there are two types of teaching general course of history. The first of them combines two disciplines: History of Russia and General history, and the second one is comprised only of one discipline: History $[1,3,6,7]$. Finally, the latter variant in fact truncates the taught knowledge, since more often its content includes factual knowledge of historical development of Russian society. This fact is even fixed in the education program, where in the five tasks of the subject mastering, three of them refer to description of problems of Russian history, and the two remained tasks - to general historical notions and categories $[1,3]$. In other words, the disciplines History and History of Russia are formally considered as coinciding in terms of their quantitative and qualitative filling, though, in practice, unofficially, they are defined as one and the same.

This situation leads not only to incomplete disclosure of overall picture of historical knowledge but also interferes with formation of complete professional worldview of students as future specialists. At the same time, under the existing conditions, a social humanitarian science, especially history, defines its relevant objective as attempt to imply regulating impact on the processes of globalization in society and to eliminate their spontaneous negative consequences. With this aim, the global civilization approach to education is proposed, which is denoted as meta-education, that is, consideration of education from 
certain positions being as generalized as possible, raising the point of view to the level of world trends $[5,8,9]$.

We should address the experience of teaching history in other countries, where this issue is being analyzed for a long time. The main concept is necessity to overcome the tradition of fragmentary coverage of historical knowledge presented only in the context of national history; on the contrary, the latter should be presented in the frames of human history. Only in this case a student can obtain common vision of meaning and significance of historical facts [10-16].

In this regard, the History course should be completely reinterpreted while arranging its content on the basis of coverage of common features of human history as of single social organization.

The topics of lectures should be arranged as follows:

1. Introduction to History (object and subject of research, meaning, objective, tasks and principles of history as science, philosophy of history, historical facts, methods and sources, as well as their classification, structure of history studies, main and auxiliary historical disciplines, historical laws and regularities).

2. History periodization (general characteristic of historical periods (Prehistoric, Protohistoric, and Historic eras), formational and civilizational approaches, technocratic, world-system, and evolutional theories of history periodization, three-age system, ecumene concept, historical chronology and calendar).

3. Prehistoric era (features, peculiarities, and stages of Prehistoric era, theories of origin and ancestral home of humanity and human society, people generations, primitive communal system, primitive human herd, communal system, Neolithic revolution, Great social division of labor).

4. Ancient world (features, peculiarities, and stages of Ancient world, Ancient East and Anticity, ancient east and slave-owning system, Phoenician, Great Greece and Roman colonization of the Mediterranean, Axial Age, the first Scientific Revolution).

5. Middle ages (features, peculiarities, and stages of Middle Ages (Dark Ages, Early, Classic, and Late Middle Ages), feudalism, Middle Age Europe, Byzantium, Middle Age East, The Great Migration of Peoples, Arab conquests, Mongol conquests, Crusades).

6. Precolonial period (features, peculiarities, and stages of Precolonial period, PreColumbian America (Mesoamerica and Andean region), Precolonial Black Africa and Oceania, precolonial system, European colonization).

7. Modern Age (features, peculiarities, and stages of Modern Age (Early Modern Age, Renaissance, Age of Enlightenment, Long 19th century), industrial society, capitalism, colonialism, imperialism, Age of discovery, Cultural exchange, Economic revolution, Westphalian and Vienna systems of international law, the Second and the Third scientific revolutions, Reformation and Counter-Reformation, bourgeois revolution and bourgeoisdemocratic revolutions, the Second and the Third industrial revolutions).

8. Contemporary history (features, peculiarities, and stages of Contemporary history (Interwar and Postwar periods, Contemporary period), informational society, socialism, postcapitalism, neo-colonialism, Superpowers, World wars, Cold war, Versailles-Washington and Yalta-Potsdam systems of international law, scientific and technological revolution).

Let us exemplify the distribution of education plans. Thus, in Plekhanov Russian University of Economics and Financial University, the working programs for History course of intramural and intra-extramural forms of education of bachelor department assume 8 lectures (16 classroom hours), and that of extramural form of education -4 lectures ( 8 classroom hours). The number of seminars for intramural and intra-extramural forms of education is 17 classes ( 34 classroom hours), for accelerated form of education - 9 classes (18 classroom hours), and for extramural form of education -4 classes ( 8 classroom hours) $[1,3]$. 
Therefore, the lecture course can be distributed equally among the mentioned topics: one lecture per one topic for intramural and intra-extramural forms of education, and by halves for extramural form of education. Seminars can be distributed as follows: two seminars per one topic for intramural and intra-extramural forms of education; one seminar - for accelerated form of education, while the last two class hours should be devoted to generalization of the studied material; and by halves - for extramural form of education.

\section{Conclusion}

There exists obvious necessity to review the program concept of History course presented at nonhistory faculties and nonhistory universities of Russia in order to combine factual knowledge of both Russian and foreign history. Moreover, in order to avoid free interpretation of the course title regarding its content and eliminate confusion, its renaming should be considered. New name can be, for instance, Synchronous history, General history, World history.

\section{References}

1. E.A. Ageyeva, Istoriya. Rabochaya programma distsipliny dlya studentov, obuchayushchikhsya po vsem napravleniyam podgotovki programm bakalavriata (ochnaya i zaochnaya formy obucheniya) [History. The work program of the discipline for students studying in all specialties of undergraduate programs (full-time and parttime)] (Financial University under the Government of the Russian Federation, Moscow, 2018)

2. N.Yu. Kolokoltseva, Vzaimosvyaz shkolnogo $i$ vuzovskogo prepodavaniya istorii v sovremennykh usloviyakh [The relationship between school and university teaching of history in modern conditions], in Istoriko-kulturnyy standart v sisteme FGOS: sistemnyy podkhod k prepodavaniyu istorii v shkole i vuze: Sb. materialov vseros. seminara [Historical and cultural standard in the FSES system: a systematic approach to teaching history at school and university: Collection of materials of the all-Russian seminar], 17-20 (Publishing house of the Tula State Lev Tolstoy Pedagogical University, Tula, 2016)

3. I.M. Kornilova, Rabochaya programma uchebnoy distsipliny B1.B.01.01. Istoriya [Work program of the academic discipline B1.B.01.01. History] (Plekhanov Russian University of Economics, Moscow, 2020)

4. M.V. Salimgareyev, A.Yu. Suslov, Sh.S. Khammatov, Obrazovaniye i nauka, 19(9), 70-85 (2017)

5. K.A. Ushmayeva, Vestnik Stavropolskogo Gosudarstvennogo Universiteta, 51, 9-14 (2007)

6. I.M. Kornilova, A.S. Fomina, Rabochaya programma uchebnoy distsipliny B1.O. Istoriya (modul). Istoriya Rossii [Work program of educational discipline B1.O. History (module). Russian history] (Plekhanov Russian University of Economics, Moscow, 2018)

7. I.M. Kornilova, A.S. Fomina, Rabochaya programma uchebnoy distsipliny B1.O. Istoriya (modul). Vseobshchaya istoriya [Work program of educational discipline B1.O. History (module). World history] (Plekhanov Russian University of Economics, Moscow, 2018)

8. V.A. Tishkov, Novaya istoricheskaya kultura [New historical culture] (Publishing house of the Moscow Psychological and Social Institute, Moscow, 2011) 
9. A. Zubrilina, Koncept, S8, 6-10 (2017). Accessed on: December 20, 2020. [Online]. Available: http://e-koncept.ru/2017/470099.htm

10. M. Duglas, How institutions think (Syracuse University Press, Syracuse, 1986)

11. L. Greenfield, Nationalism: five roads to modernity (Harvard University Press, Cambridge, Massachusets, 1992)

12. J.W. Loewen, Lies across America: what our historic sites get wrong (New Press, New York, 1999)

13. J.W. Loewen, Lies my teacher told me: everything your American history textbook got wrong (New Press, New York, 1994)

14. J.W. Loewen, Revising state and local history books (Vance Bibliographies, Monticello, 1980)

15. J. Zimmerman, Whose America?: Culture wars in the public schools (Harvard University Press, Cambridge, Massachusets, 2002)

16. M. Hildermeir, Geschichte Russland: vom mittelalter bis zur Oktoberrevolution [History of Russia: from the middle ages to the October revolution] (C.H. Beck, Munchen, 2013) 